\title{
Fostering Creativity and Improvement of Secondary School Students' Attitude Towards Physics: A Way Forward for Sustainable Development in Nigeria
}

\author{
Agommuoh, P. C \\ Department of Science Education, Michael Okpara University of Agriculture, Umudike, Abia \\ State - Nigeria.
}

\begin{abstract}
The study is aimed at identifying strategies that could be employed in fostering creativity in secondary school physics students and improving secondary school students' attitude towards the study of physics for sustainable technological development in Abia State of Nigeria. All the 80 physics teachers in the state were used for the study. The instrument for data collection was the researcher's developed structured questionnaire of the Likert type. The reliability of the instrument was obtained as $r=0.89$. Five research questions and one null hypothesis guided the study. Data collected was analyzed using mean for the research questions and Chi-Square $\left(X^{2}\right)$ statistics for the hypothesis. Findings revealed that teachers agreed that learning activities like brainstorming, problem solving, openended discussion, cooperative learning among others help to foster creativity in physics students while employment of qualified/professional physics teachers to teach the subject, provision of adequate instructional materials/equipments, provision and adequate use of teaching aids and tools, adequate use of recommended textbooks, intensive funding of schools by managements/government, proper use of the library by both students and teachers, adequate motivation of both teachers and students, conducive and comfortable learning environment and adequate use of the physics laboratory are all strategies that could be used to improve secondary school student's attitude towards the study of physics for sustainable technological development in Abia State of Nigeria. Based on this, recommendations were made.
\end{abstract}

\section{Introduction}

The goal of science education among others is to educate student to be able to adapt to different conditions, be flexible thinkers, ask questions, be creative and even think critically Aktamis \& Yerice, [1]. Supporting this, Liliasari [2] opined that students need to master critical thinking and creative thinking skills since it can be used to protect themselves and others as well as for making important everyday lives decisions. Creativity according to Ripple [3] is behaved to be a combination of abilities, skills, motivation, attitudes and other factors. This is why Plucker and Runco [4] believe that techniques for enhancing creativity involved divergent thinking and general problem solving heuristics.

Creativity is not only the ability to come up with new ideas but also narrowly down those ideas to focus on one that can be elaborated (Ndirika \& Agommuoh, [5]. Creativity involves two processes: thinking and then producing. Torrance [6] explained that the core components of divergent thinking are fluency (generating a large numbers of ideas), flexibility (generating ideas of different approaches), novelty (generating unusual ideas) and elaborating (generating ideas in detail). According to Williams [7], curiosity, imagination, challenge- taking and risk taking attitudes are very conducive to creativity development and motivational factors like interest, confidence and value in creative thinking are also important determine of divergent thinking.

Science education enables individuals to use scientific process skills which will enable students to define problems around. In order to do this, students should be able to hypothesize experiment, conclude, generalize and even to apply the information to the necessary scientific skills (Meador,) [8]. Students need to think creatively to be able to able to use these process skills for the development of a fundament scientific understanding. Many scholars have suggested that creativity development is inherited in scientific process. Craft [9], Pye and Sherborne [10] and Meador [8] explained that engaging students in the active thinking in the open-ended scientific discovery and inquire process are means to foster students creativity. They went further to explain that students are encouraged to form their own 
hypotheses and develop their own experimental designs which will foster creativity in science.

Physics as one of the pre-requisite subjects for the study of engineering, medicine, technological and other applied science courses in the university is very imperative for national development. Physics is an international enterprise which plays a key role in the future progress of humankind.

For a nation to develop a sound basis for modern technology, the study of physics which enhances an understanding of the interplay of forces which forms veritable armour against superstition anywhere is very necessary. Physics studies the laws of nature that govern the behaviour of the universe, from the very smallest scales of sub-atomic particles to the very largest scales of cosmology. Physics is a science that observes natural phenomena and explains them by using general rules to describe what has been observed. This is why Ayodele and Anyaegbuna[11] opined that today's physics has two sides, on the one hand, it provides the basis for our current world picture, while on the other hand, it is the foundation of other subjects for technological developments. The study of physics can lead to several scientific fields and professions making its study and knowledge to play a very significant role in the economic development of any nation. It is in realization of these qualities that physics was introduced in Nigerian senior secondary schools to achieve the attainment and realization of our national goals and objectives with regards to the development of science and technology in Nigeria (Ayodele \&Anyaegbuna,[11]). Unfortunately the learning of physics in secondary schools has been observed to have some flaws that include:

1. Using the lecture method which is teacher centred to teach physics.

2. Concentrating on the use of textbooks and not exploring other teaching materials.

3. Laying more emphasis on the mathematical computations than the physics concepts.

4. Learning process is confined to reading and memorization - critical and creative skills are rarely developed.

Various learning activities have been observed to foster critical and creative thinking in physics. Miri, Ben-chairn \& Dan Zollarr, [12] opined that learning real world problem solving, open-ended discussion and inquiry-based experiment can improve critical thinking skills in students. Explaining further Chi, Khang, San \& Wah [13] used three learning strategies that include teacher questioning, discrepant event and word juxtapose in a cooperative learning environment to improve critical thinking skills and creativity in learning science. Tiong [14] also reported that cooperation learning and the use of experiment have proven to improve learning skills like attitudes, thinking skills and knowledge of physics in students. There is therefore the need to find out from physics students if there are learning strategies that can be used in the teaching of secondary school physics that could improve creative and critical thinking in them.

Attitudes according to Hendrickson [15], are the best predictor for estimation of students' success and can be acquired through learning and changed through persuasion using variety of techniques. Adesina and Akinbobola [16] opined that although attitude changes gradually, people constantly form new attitudes and modify old ones when they are exposed to new information and new experiences thereby helping to shape the experiences the individual has with people, objects or subjects. The importance of the study of physics cannot be overemphasized as it forms the basis for technological advancement of any nation. It is based on this that it is imperative to improve students' attitudes towards the study of physics. Students' negative attitudes towards physics could be attributed to so many factors which includes poor teaching methods, poor learning environments, poor teacher/student relationship, lack of interest from the students, lack of teaching aids/materials, poor classroom arrangement, lack of laboratory, poor government policies and use of unqualified and inexperienced physics teachers. Learning physics concepts is very necessary since accelerated changes of the last decades in technology have brought discipline, curriculum and philosophical changes. Hence this research tends to find out if there will be any change in the attitude of secondary school students towards physics when strategies to improve their attitudes are identified and implemented.

There has always been an interest in the development of positive students' attitudes towards physics. It is really impossible to learn and understand physics when factors related to students' attitudes towards physics are not indemnified as a matter of urgency and feasible strategies and interaction programme organized to help address the problem and hopefully encourage the students to adopt meaningful and positive attitudes towards physics. This is why Omosewo[17] stressed the need for teachers to have an understanding of their students' knowledge and feelings about the subject they teach. The study therefore aimed at identifying factors that will help to improve the attitudes of students towards the study of physics in secondary schools in Umuahia North Local Government Area of Abia State of Nigeria for sustainable technological development.

The purpose of the study is to indentify strategies that will foster creativity and improve the attitudes of secondary school students towards the study of 
physics for sustainable technological development in Umuahia North Local Government Area of Abia State. Specifically, the study tends to:

1. Investigate secondary school teachers' assessment of learning activities that can foster creativity in physics students.

2. Identify teachers' factors that will improve students' attitude towards physics.

3. Identify students' factors that will improve students' attitude towards physics.

4. Identify teaching materials, best arrangement pattern of laboratory and classroom that will increase students' interest and performance in physics.

\section{Research Questions}

The following research questions guided the study.

1. What are the scores of secondary school physics teachers' on the assessment of learning activities that can foster creativity in physics students?

2. What are the scores of male and female secondary school physics teachers' on the assessment of learning activities that can foster creativity in physics students?

3. What are the teachers' attitudes that affect students' performance in the study of physics?

4. What are the students' factors that can help improve their attitudes towards physics?

5. What are the teaching materials, equipments, tools in teaching physics and arrangement pattern that can help improve students' attitudes towards physics?

\section{Hypothesis}

The hypothesis below guided the study.

Ho: There is no significant difference in the scores of male and female secondary school physics teachers' assessment of the learning activities that can foster creativity in physics students.

\section{Method}

The study employed the survey design to investigate strategies that could be employed foster creativity in physics students and improve secondary school student's attitude towards the study of physics for sustainable technological development in Abia State of Nigeria.

All the 80 physics teachers in all the secondary schools in Umuahia North Local Government Area of Abia State were used for the study. The instrument for data collection was the researcher's developed structured questionnaire of the Likert type. The questionnaire on the strategies that could be employed to foster creativity in physics students and improve secondary school students' attitude towards the study of physics for sustainable technological development in Abia State of Nigeria, is a twenty-five item questionnaire rated on a 4-point scale of degree of agreement or disagreement having the options of Strongly Agree $(\mathrm{SA})=4$, Agree $(\mathrm{A})=$ 3 , Disagree $(\mathrm{D})=2$ and Strongly Disagree $(\mathrm{SD})=1$. The reliability of the instrument was obtained as $r=$ 0.89 . The questionnaires were distributed by the researcher and collected back to ensure 100 percent return. Five research questions and one null hypothesis guided the study. The research questions were answered using mean and the hypothesis tested using Chi- Square $\left(\mathrm{X}^{2}\right)$ statistics. 


\section{Result}

The results of the study are presented in the tables below.

Table 1: Mean score of secondary school physics teachers' assessment of the learning activities that can foster creativity in physics students.

\begin{tabular}{|l|lccccc|c|}
\hline S/N & Learning Activities & SA & A & D & SD & $\overline{\mathbf{X}}$ & Remark \\
\hline 1. & Problem Solving & 45 & 20 & 12 & 3 & 3.34 & Agree \\
2. & Open Ended discussion & 40 & 35 & 5 & - & 3.44 & Agree \\
3. & Inquiry-based & 38 & 40 & 3 & 2 & 3.50 & Agree \\
4. & Cooperative learning & 35 & 20 & 15 & 10 & 3.00 & Agree \\
5. & Questioning & 25 & 40 & 10 & 5 & 3.06 & Agree \\
6. & Problem Finding & 42 & 30 & 5 & 3 & 3.39 & Agree \\
7. & Making Prediction & 50 & 20 & 10 & - & 3.50 & Agree \\
8. & Creating Analogies & 43 & 30 & 3 & 4 & 3.40 & Agree \\
9. & Brain Storming & 30 & 35 & 10 & 5 & 3.13 & Agree \\
10. & Open Inquiry & 25 & 40 & 8 & 7 & 3.04 & Agree \\
11. & Multiple examples & 20 & 44 & 10 & 6 & 2.98 & Agree \\
12. & Creative writing & 35 & 40 & - & 5 & 3.31 & Agree \\
13. & System Deign & 40 & 25 & 5 & 10 & 3.19 & Agree \\
\hline
\end{tabular}

Result in table 1 above showed that all the items have mean score values between 2.98 and 3.50. These mean values are greater than 2.5 which is the mean value of the four point scale used for the study. This shows that all the physics teachers agreed that all the activities listed above can foster creativity in physics students.

Table 2: Mean Score of male and female secondary school physics teachers 'assessment of learning activities that can foster creativity in physics students.

\begin{tabular}{|c|c|c|c|c|c|c|c|c|c|c|c|c|}
\hline \multirow[t]{2}{*}{$\mathbf{S} / \mathbf{N}$} & \multirow[t]{2}{*}{ Learning Activities } & \multicolumn{2}{|r|}{ SA } & \multicolumn{2}{|c|}{$\mathbf{A}$} & \multicolumn{2}{|c|}{ D } & \multicolumn{2}{|c|}{ SD } & \multicolumn{2}{|c|}{$\bar{X}$} & \multirow[t]{2}{*}{ Remark } \\
\hline & & M & $\mathbf{F}$ & $\mathbf{M}$ & $\mathbf{F}$ & $\mathbf{M}$ & $\mathbf{F}$ & $\mathbf{M}$ & $\mathbf{F}$ & $\mathbf{M}$ & $\mathbf{F}$ & \\
\hline 1. & Problem Solving & 28 & 17 & 18 & 2 & 2 & 10 & - & 3 & 3.54 & 3.03 & Agree \\
\hline 2. & Open Ended discussion & 28 & 12 & 20 & 15 & - & 5 & - & - & 3.58 & 3.22 & Agree \\
\hline 3. & Inquiry-based experiment & 25 & 10 & 22 & 18 & 1 & 2 & - & 2 & 3.50 & 3.13 & Agree \\
\hline 4. & Cooperative learning & 27 & 8 & 10 & 10 & 7 & 8 & 4 & 6 & 3.25 & 2.63 & Agree \\
\hline 5. & Questioning & 15 & 10 & 25 & 15 & 5 & 5 & 3 & 2 & 3.08 & 3.03 & Agree \\
\hline 6. & Problem Finding & 22 & 20 & 20 & 10 & 3 & 2 & 3 & - & 3.27 & 3.56 & Agree \\
\hline 7. & Making Prediction & 28 & 22 & 15 & 5 & 5 & 5 & - & - & 3.48 & 3.53 & Agree \\
\hline 8. & Creating Analogies & 33 & 10 & 10 & 20 & 2 & 1 & 3 & 1 & 3.52 & 3.22 & Agree \\
\hline 9. & Brain Storming & 20 & 10 & 25 & 10 & 3 & 7 & - & 5 & 3.35 & 2.78 & Agree \\
\hline 10. & Open Inquiry & 15 & 10 & 28 & 12 & 5 & 3 & - & 7 & 3.21 & 2.78 & Agree \\
\hline 11. & Multiple examples & 15 & 5 & 24 & 20 & 5 & 5 & 4 & 2 & 3.04 & 2.88 & Agree \\
\hline 12. & Creative writing & 28 & 7 & 20 & 20 & - & - & - & 5 & 3.58 & 2.91 & Agree \\
\hline 13. & System Deign & 22 & 18 & 15 & 10 & 5 & - & 6 & 4 & 3.10 & 3.31 & Agree \\
\hline
\end{tabular}

Result in table 2 showed that all the males have mean score values between 3.04 and 3.58 for all the items while all the females have mean score values between 2.78 and 3.56 for all the items. These mean score values are greater than 2.5 which is the mean score value of the four point scale used for the study. This shows that all the physics teachers both males and females agreed that all the activities listed above can foster creativity in physics students. 
Table 3: Mean Score of Teachers' Assessment of the Strategies that could be Employed to Improve Secondary School Student's Attitude Towards the Study of Physics for Sustainable Technological Development in Abia State of Nigeria.

\begin{tabular}{|c|c|c|c|c|c|c|c|}
\hline $\mathbf{S} / \mathbf{N}$ & STRATEGY & $\mathbf{S A}$ & $\mathbf{A}$ & D & SD & $\mathbf{X}$ & Remark \\
\hline 1 & $\begin{array}{l}\text { Effective use of teaching aids by physics teachers will improve } \\
\text { students' attitude towards physics. }\end{array}$ & 45 & 30 & 4 & 1 & 3.50 & Agree \\
\hline 2 & $\begin{array}{l}\text { Effective use of varieties of teaching methods by physics teachers in } \\
\text { teaching physics will improve students' attitude towards physics. }\end{array}$ & 47 & 32 & 1 & - & 3.57 & Agree \\
\hline 3 & $\begin{array}{l}\text { Qualified and professionally trained physics teachers teaching } \\
\text { physics will improve students' attitude towards physics. }\end{array}$ & 44 & 35 & 1 & - & 3.54 & Agree \\
\hline 4 & $\begin{array}{l}\text { Availability and use of recommended physics textbooks by students } \\
\text { will improve students' attitude towards physics. }\end{array}$ & 38 & 42 & - & - & 3.46 & Agree \\
\hline 5 & $\begin{array}{l}\text { Updating physics teachers knowledge through conferences, seminars } \\
\text { and workshops will improve students' attitude towards physics. }\end{array}$ & 48 & 30 & 2 & - & 3.56 & Agree \\
\hline 6 & $\begin{array}{l}\text { Motivating physics teachers through incentives will improve } \\
\text { students' attitude towards physics. }\end{array}$ & 32 & 41 & 5 & 2 & 3.29 & Agree \\
\hline 7 & $\begin{array}{l}\text { Encouraging physics students by telling them that physics is not a } \\
\text { difficult subject will improve students' attitude towards physics. }\end{array}$ & 20 & 33 & 20 & 7 & 2.83 & Agree \\
\hline 8 & $\begin{array}{l}\text { Encouraging physics teachers to teach physics in an interactive } \\
\text { manner will improve students' attitudes towards physics. }\end{array}$ & 40 & 32 & 5 & 3 & 3.36 & Agree \\
\hline 9 & $\begin{array}{l}\text { Proper arrangement of physics classrooms and laboratory in } \\
\text { order to give students a sense of belonging will improve } \\
\text { students' attitudes towards physics. }\end{array}$ & 36 & 42 & 2 & 1 & 3.44 & Agree \\
\hline 10 & $\begin{array}{l}\text { Making the teaching of physics interesting by teaching with related } \\
\text { stories will improve students' attitudes towards physics. }\end{array}$ & 50 & 30 & - & - & 3.63 & Agree \\
\hline 11 & $\begin{array}{l}\text { Proper and adequate funding of schools by equipping and } \\
\text { constructing good physics laboratories/workshops, supplying } \\
\text { relevant physics textbooks, building and equipping good physics } \\
\text { libraries and providing comfortable classroom accommodation will } \\
\text { improve students' attitudes towards physics. }\end{array}$ & 36 & 38 & 3 & 3 & 3.21 & Agree \\
\hline 12 & $\begin{array}{l}\text { Frequent and adequate conduction of physics practical and students' } \\
\text { proper and frequent use of physics materials and aids will improve } \\
\text { students' attitudes towards physics. }\end{array}$ & 40 & 36 & 4 & 1 & 3.46 & Agree \\
\hline
\end{tabular}

Table 3 above clearly showed that all the items have mean values between 2.83 and 3.63 which is greater than 2.5 which is the mean value of the four point scale used in the study. This means that all the teachers agreed that these items are strategies that could be employed to improve secondary school student's attitude towards the study of physics for sustainable technological development in Abia State of Nigeria.

Table 4: $\mathrm{X}^{2}$ Scores of male and female secondary school physics students' assessment of learning activities that can foster creativity in physics students.

\begin{tabular}{lcccccc}
\hline SEX & NO & SA & A & D & SD & TOTAL \\
MALE & 48 & 306 & 252 & 43 & 23 & $\mathbf{6 2 4}$ \\
& & $(279)$ & $(251)$ & $(58)$ & $(36)$ & \\
FEMALE & 32 & 159 & 167 & 53 & 37 & $\mathbf{4 1 6}$ \\
TOTAL & $\mathbf{8 0}$ & $(186)$ & $(168)$ & $(38)$ & $(24)$ & $\mathbf{1 0 4 0}$ \\
\hline
\end{tabular}

$\mathrm{X}^{2}$ cal $($ critical $)=28.68, \mathrm{X}^{2}$ tab $($ table $)=7.82, \mathrm{df}=3$ 
The result in table 4 showed that $\mathrm{X}^{2}$ cal (critical) $=28.68$ and this value is greater than the $\mathrm{X}^{2}$ tab (table) while is 7.82. Since $X^{2}$ cal (critical) is more than $X^{2}$ tab (table), the null hypothesis is rejected. This means that there is a significant difference in the opinions of male and female physics teachers as to the learning activities that can foster creativity in physics students.

\section{Discussion}

From tables 1 and 2, it is observed that all the physics teachers agreed that the listed learning activities are learning activities that can foster creativity in physics students. This study is in agreement with the works of Mari, Ben Chain \& Dan Zoller [12] who stressed that learning real world problem solving, open-ended discussion and inquiring based experiment help in fostering creativity in the learner. Aktamis \& Yerice [1] supports the result of this study by explaining that creativity enhancement programs also involve the learning of specific idea generating heuristics like brainstorming, mind- mapping, force association, check-listing, creating metaphors and creative dramatics.

The result of the study is also in line with the opinions of Treffinger, Isaksen and Dorval [18] who explained that among other techniques, brainstorming technique and creative problem solving technique are most widely adopted in creative learning activities.

According to Joyce, Weil and Calhoun [19] the major role of education is to improve the capacity of the students in terms of the development of social learning where cooperative learning is more meaningful in the improvement and enrichment of students' learning experience. There is therefore the tendency of cooperative learning to strengthen the contribution of each individual in achieving collective goals thereby providing a positive effect on students learning (Dyson \& Grineski, [20] Craig, Van Lehn and Chi [21] in their study, reported the use of questions to support understanding, problem - solving and reasoning which encourages the achieve involvement of students in the learning process thereby enhancing creativity in students.

Table 3 showed that the use of teaching aids, variety of teaching methods, professionally trained and qualified physics teachers to teach physics in secondary schools will improve secondary school student's attitude towards the study of physics for sustainable technological development in Abia State of Nigeria. This agrees with Ogwa [5] who stated that teachers who use teaching aids to teach their lessons convey more facts and make the lessons more interesting than teachers who teach without the use of teaching aids. According to Ogwa [5], teaching with teaching aids and also a variety of teaching methods makes the lesson more meaningful since teaching methods are vehicles used to convey the objectives of a lesson in such a way that the learner can best acquire knowledge at the end the lesson. This means that varieties of teaching methods should be used by physics teachers for them to choose the most suitable method for a particular topic.

Table 3 also shows that availability and use of recommended physics textbooks, updating physics teachers knowledge through conferences, seminars and workshops, motivating physics teachers through incentives, encouraging physics students by telling them that physics is not a difficult subject, encouraging physics teachers to teach physics in an interactive manner, proper arrangement of physics classrooms and laboratory in order to give students a sense of belonging, making the teaching of physics interesting by teaching with related stories, proper and adequate funding of schools by equipping and constructing good physics laboratories/workshops, supplying relevant physics textbooks, building and equipping good physics libraries and providing comfortable classroom accommodation, frequent and adequate conduction of physics practical and students' proper and frequent use of physics materials and aids will improve physics students' attitudes towards physics.

Physics teachers have the responsibility of recommending good physics text books to their students and guide them in the use of these text books. Supporting proper arrangement of physics classrooms and laboratories as a strategy for improving students attitude towards physics, Ricardo [6] suggested that physics teachers should arrange their classrooms and laboratories in a way that it will give room for effective interaction among students and between students and the teacher. Stressing on motivating physics teachers through incentives, Oguntimehin[7] stated in his study that poor and irregular payment of salary, no hope of owing a car, low prestige in society due to lack of finance are some major factors that affect teachers in delivering their lessons properly. Findings of the study agreed with the concern of Omosewo[8] who opined that prospective physics teachers should be well grounded in the subject. A situation in which what is learnt in the school is hardly reflective of the future encounter of the 
student is not desirable. Teaching physics should not be done by those who cannot find jobs elsewhere but by qualified and professionally well trained physics teachers who can deliver.

Result in table 4 indicated that there is a significant difference in the opinions of male and female students on these learning activities that can foster creativity in the student. This means that gender played a role.

\section{Conclusion}

The study revealed that for fostering of creativity in physics students, , the physics teacher has to teach the students using learning activities like brainstorming, problem solving, open-ended discussion, inquiry based experiments, cooperative learning, creating analogies, open inquiry and the likes.

Poor and negative students attitudes towards physics has been of great concern to physics educators. Researches have been done to identify strategies that could improve students' attitudes towards physics and such strategies have been identified to include the use of qualified and professional physics teachers to teach physics, use of teaching aids by physics teachers, use of varieties of teaching methods by physics teachers in teaching physics, building and equipping good physics libraries and providing comfortable classroom accommodation, frequent and adequate conduction of physics practical and students' proper and frequent use of physics materials and aids. Based on this, some recommendations were made.

For fostering creativity in physics students and the improvement of secondary school students' attitude towards physics for sustainable technological development in Abia State- Nigeria, the following recommendations are made:

1. Physics teachers should expose the physics students to learning strategies like brainstorming, questioning, cooperative learning and others in order to foster creativity in their students.

2. Workshops, seminars and conferences on creative learning strategies should be frequently organized for serving physics teachers to update them on such learning strategies.

3. Physics teachers must provide conducive learning environment for physics students in order to foster creativity in them.

4. Physics students should be encouraged to participate fully in the learning process.

5. Students should be provided with detailed feedback of their performance and be encouraged to engage in inquiry based activities that will improve their critical and creative thinking.

1. Physics teachers should be encouraged to make effective use of teaching aids while teaching physics.

2. Physics teachers should use a variety of teaching methods in teaching physics so as to find out the best method for a particular topic.

3. Government should employ qualified and professionally trained physics teachers to teach physics in the secondary schools.

4. Recommended physics textbooks should be made available by the government to be used by students.

5. The knowledge of physics teachers should be updated through conferences, seminars and workshops and also physics teachers should be motivated through incentives.

6. Physics teachers should ensure frequent and adequate conduction of physics practical and students' proper and frequent use of physics materials and aids, teaching physics in an interactive manner to make interesting and providing comfortable classroom accommodation to give students room to interact among themselves.

7. The school management/ government should provide conducive and comfortable learning environments, teaching materials/equipments and teaching aids, well equipped libraries and laboratories for effective teaching and learning of physics.

8. The schools should also be adequately funded and incentives should also be provided to both the students and teachers by the school management/government in order to motivate them.

\section{References}

[1]. O. Ayodele and B. Anyaegbuna. An assessment of physics audiovisual teaching and learning resources at the tertiary level, in Lagos and Ogun States. 2012. pp 358-366.

[2]. A. B. Hendrickson. Predicting students' success with the learning and strategies14 Inventory (LASSI). Unpublished Master's Thesis. Iowa State University.1997.

[3]. A. O. Adesina and A. O. Akinbobola. The attitude of students towards part - time degree programme of the faculty of education, Obafemi Awolowo University, Ile Ife. Journal of Research in Education.2005, 2(1), pp 1 4.

[4]. E. O. Omosewo. Physics educators' perception of problems militating against effective teaching of 
physics in Nigerian secondary schools. Journal of Educational Theory and Practice, 1999.5 (1\&2) pp 1- 11.

[5]. C. E.Ogwa. Effective teaching method: Enugu cheston ltd.2002.

[6]. T. Richardo. Factors affecting Junior High School students interest in physics. Journal of Science Education and Technology.2006. Vol 15 No. 1

[7]. A. Oguntimehin. Influence of teachers professional qualifications on academic performance of students in physics. Available in the Department of Science Education, University of Ilorin, Ilorin, Nigeria.1987.

[8]. E. O. Omosewo. In service programmes for senior physics teachers for improved teaching and assessment of students. Nigerian Journal of Development Issues: Education Socio-Political and Economic Development 2001. 5(1\&2), pp 200-219. 